\title{
Calculation the Equity Level of an Internet Service
}

\author{
Sigit Haryadi \\ Institut Teknologi Bandung \\ March 2018
}

Preprint DOI10.17605/OSF.1O/UZCMQ

Citation: Haryadi, S. (2018, March 6). Calculation the Equity Level of an Internet Service. Retrieved from osf.io/uzcmq

\begin{abstract}
The method of calculating the level of equity of internet services of several cities or provinces in a country is a statistical measure showing how far the internet service speed distribution being measured is to have similarities with the reference distribution of all elements equal to one, where the determination of the level of equity is done by calculating the Index Haryadi from the relationship between internet service speed distribution as measured by reference distribution. In this case, an equalization index equal to one represents a perfect similarity between the elements of the distribution as measured by the pairs of elements of the reference distribution. Let $R$ be the reference distribution = \{0.7 Mbps; 0.8 Mbps; 0.9 Mbps; 1 Mbps; 1.1 Mbps; 1.2 Mbps; 1.3 Mbps; 1.4 Mbps $\}$ and $Y$ is the measured internet rate $==1.05 \mathrm{Mbps} ; 1.2 \mathrm{Mbps} ; 1.35 \mathrm{Mbps} ; 2 \mathrm{Mbps} ; 1.65 \mathrm{Mbps} ; 1.8$ Mbps; 1.95 Mbps; 2.1 Mbps\}, then Y has an Internet service equalization index equal to one, through the $Y=1.5 R$ relationship function because all elements of $Y$ are equal to 1.5 times of the pairing elements of $R$.
\end{abstract}

\section{Internet Calculator}

To simplify calculations, an internet calculator has been created, i.e. a website that provides a field of content, where we can fill in the information or data about the speed of service in some cities or provinces to be measured in the level of equity.

Procedure: (1) Fill in the number of cities or number of provinces in a country that will be measured equity of its internet service; (2) Fill in information or data about internet speed in each city or province and fill in referral distribution; (3) Click CALCULATE

The website address is on the "Calculation the Equity Level of an Internet Service" link on my homepage at http://sigitharyadi.net/ 


\section{Calculation Explanation}

I. Calculate the share of the internet velocity in the measured cities or provinces, using the formula: $\mathrm{Si}=$ (internet speed in a city or a province divided by total from internet speed).

II. Then calculates the index of the equity of internet services, using the following formula "Haryadi Index":

$$
H I=\frac{1}{\left[N^{*}\left\{\sum_{i=1}^{N} S_{i}^{2}+\sum_{i=1}^{N} \sum_{j=1}^{N}\left(S_{i}-S_{j}\right)^{2}\right\}\right]} ; i>j
$$

II. Then determines the level of competition as follows:

a) The Haryadi index between 0.90 and 1.00 corresponds to an excellent level of Internet service equity.

b) The Haryadi index between 0.75 and 0.89 corresponds to a good level of Internet service equalization.

c) The Haryadi index between 0.60 to 0.74 corresponds to an almost poor level of Internet service distribution.

d) The Haryadi index between 0.50 and 0.59 corresponds to a poor level of Internet service distribution.

e) The Haryadi index of less than 0.50 is corresponding to the extremely poor level of Internet service distribution.

\section{Notes}

In order to understand the concept of "Haryadi Index" that became the spirit of this calculator, please read my writings in the following bibliography

\section{References}

[1] Dyah Rakhma Ariyanti; Sigit Haryadi. (October 2017). Analysis of Harmony In Gradation Index on 5G Cellular Network Quantitative Analysis. The 11th International Conference on Telecommunication Systems, Services, and Applications, At Lombok, Indonesia.

[2] Haryadi, S. (2017, November). Probabilitas Statistik Untuk Insinyur. Researchgate. DOI10.13140/RG.2.2.14304.58885

[3] Haryadi, S. (2018, February 1). Indeks Haryadi dan Prospeknya Untuk Menjadi Suatu "Formula of Everything (versi 31 Desember 2017). Retrieved from osf.io/zex45

[4] Haryadi, S. (2018, February 1). KALKULATOR untuk membuat Regresi Linier Tanpa Intersep. Retrieved from osf.io/emvs7 
[5] Haryadi, S. (2018, February 1). Kalkulator Untuk Mengukur Tingkat Kompetisi di suatu Industri, dengan menggunakan rumus Indeks Haryadi. Retrieved from osf.io/fy $7 \mathrm{zu}$

[6] Haryadi, S. (2018, February 17). Calculation the Competition Levels between Students in Class and the Relation to the Teacher or Lecture Fairness in Teaching. Researchgate. DOI10.13140/RG.2.2.30359.06569

[7] Haryadi, S. (2018, February 17). Perhitungan Tingkat Kompetisi antar Murid atau Mahasiswa di Kelas dan Kaitannya Dengan Keadilan Guru atau Dosen Dalam Mengajar. Retrieved from osf.io/a894w

[8] Haryadi, S. (2018, February 22). Equality Correlation Calculation. Researchgate. DOI10.13140/RG.2.2.22068.76168

[9] Haryadi, S. (2018, February 22). Kalkulator Untuk Menghitung Korelasi Kesetaraan. Retrieved from osf.io/preprints/inarxiv/7r9jy

[10] Haryadi, S. (2018, February 24). Calculation of "Channel Cavity" on Data Communications. Equality Correlation Calculation. Research gate.

DOI10.13140/RG.2.2.30536.01288

[11] Haryadi, S. (2018, February 24). Perhitungan "Rongga Kanal” pada Komunikasi Data. Retrieved from osf.io/preprints/inarxiv/y3wcg

[12] Haryadi, S. (2018, February 28). Ikhtisar Organisasi Regulasi Telekomunikasi. Retrieved from osf.io/preprints/inarxiv/g9m3k

[13] Haryadi, S. (2018, February 7). Statistik Terapan: Pengujian Regulasi \& Kebijakan Telekomunikasi. Retrieved from osf.io/3pkfw

[14] Haryadi, S. (2018, January 25). Chapter 1. The Concept of

Telecommunication Network Performance and Quality of Service. Retrieved from osf.io/mukqb

[15] Haryadi, S. (2018, January 26). Chapter 2 of Network Performance and Quality of Service: Determination of Key Performance Indicator (KPI). Retrieved from osf.io/preprints/inarxiv/6gtnd

[16] Haryadi, S. (2018, January 26). Chapter 3 of Network Performance and Quality of Service: Technical Measurement of a Mobile Network Performance and Quality of Service. Retrieved from osf.io/q4wsz

[17] Haryadi, S. (2018, January 30). Basic Calculation of the Network's Availability and Reliability (Chapter 4 of Network Performance and Quality of Service). Retrieved from osf.io/preprints/inarxiv/z5mwq

[18] Haryadi, S. (2018, March 1). Kebijakan Lisensi Telekomunikasi. Retrieved from osf.io/7wbjf

[19] Haryadi, S. (2018, March 5). Performance Measurement of Internet Service. Retrieved from osf.io/9nsw3

[20] Haryadi, S., \& Riani, W. (2018, March 5). METODE PENETAPAN TARIF PAJAK PENGHASILAN YANG BERKEADILAN. Retrieved from osf.io/preprints/inarxiv/ayg58

[21] Nie Levin Kusuma Adiatma ; Sigit Haryadi. (2017, October). Comparison of the Haryadi Index with Existing Method in Competition, Equality, Fairness, and Correlation Level Calculation Case Study: Telecommunication Industry. The 11th International Conference on Telecommunication Systems, Services, and Applications, At Lombok, Indonesia.

[22] Sigit Haryadi. (2016). Haryadi Index for Competition, Equality and Correlation Evaluation. Penerbit Lantip Safari Media, Bandung, Indonesia. ISBN978$602-73231-3-2$ 
[23] Sigit Haryadi. (2016). Haryadi Index untuk Evaluasi Kompetisi, Kesetaraan dan Korelasi. Penerbit Lantip Safari Media, Bandung, Indonesia. ISBN978-60273231-3-1

[24] Sigit Haryadi. (2017). Calculation of the Mobile Communication Competition using Haryadi Index. DOI10.13140/RG.2.2.15634.25280

[25] Sigit Haryadi. (2017). Harmony in Gradation and its prospects as the Formula of Everything, First edition of posts: December 31, 2017. Researchgate.

DOI10.13140/RG.2.2.19309.08169

[26] Sigit Haryadi. (2017). Haryadi Index and Its Applications in Science of Law, Sociology, Economics, Statistics, and Telecommunications. Penerbit Elex Media Komputindo. Jakarta. ISBN978-602-02-9895-5.

[27] Sigit Haryadi. (2017). Indeks Haryadi dan Penerapan di Ilmu Hukum, Sosiologi, Ekonomi, Statistik, dan Telekomunikasi. Penerbit Elex Media Komputindo, Jakarta. ISBN978-602-02-9896-2

[28] Sigit Haryadi. (2017). the Equality Correlation Method. Researchgate. DOI10.13140/RG.2.2.10443.80169.

[29] Sigit Haryadi. (2017). the Non-Intercept Linear Regression Method. Researchgate. DOI10.13140/RG.2.2.18721.71522

[30] Sigit Haryadi. (2017). The. Fairness over Inequality Index: Unfairness is Disaster - a notebook of Sigit Haryadi. Researchgate.

DOI10.13140/RG.2.2.34379.49449.

[31] Sigit Haryadi. (2017, December). Calculator for Measurement the Competition Index \& Level. Researchgate. DOI10.13140/RG.2.2.23626.26568

[32] Sigit Haryadi. (2017, December). Calculator for non-intercept linear regression. Researchgate. DOI10.13140/RG.2.2.15761.94562.

[33] Sigit Haryadi. (2017, January). Calculation of the Income Equality Levels between Regions using the Haryadi Index. Researchgate.

DOI10.13140/RG.2.2.36605.77282

[34] Sigit Haryadi. (2018, February). Applied Statistics for Assessment of the Regulation and Policy: case study in Telecommunication Industry.

DOI10.13140/RG.2.2.15774.02884

[35] Sigit Haryadi; Dyah Rakhma Ariyanti. (October 2017). The Fairness of Resource Allocation and Its Impact on 5G Ultra-Dense Cellular Network Performance. The 11th International Conference on Telecommunication Systems, Services, and Applications, At Lombok, Indonesia.

[36] Westi Riani; Sigit Haryadi. (2017). CALCULATOR for the Government to make the Fair Policy of Tax Rates. Researchgate. DOI10.13140/RG.2.2.18550.50246. Available online at http://sigitharyadi.net/multidicipline/income-tax-rates-calculatorid/

[37] Westi Riani; Sigit Haryadi. (2017). The Method Of Tax Rate Determination Based On Fairness. Prosiding Seminar Nasional SNaPP2017, Bandung, Indonesia. 